\title{
CANOPY ARCHITECTURE AND MORPHOMETRY OF TREE SPECIES USED IN THE URBAN FOREST
}

\author{
Tamara Ribeiro Botelho de Carvalho Maria ${ }^{1 *}$, Bruna Fernanda Heck Bomm² ${ }^{2}$ Juliane Nesi ${ }^{3}$, Tatiane Lima $\mathrm{Ho}^{4}$, \\ Rogério Bobrowski ${ }^{5}$ \\ ${ }^{1 *}$ Federal University of Paraná, PhD student in Forest Engineering, Curitiba, Paraná, Brazil - trbotelhomaria@gmail.com \\ ${ }^{2}$ Federal University of Paraná, Master in Forestry Engineering, Curitiba, Paraná, Brazil - brunafhbomm@gmail.com \\ ${ }^{3}$ Federal University of Paraná, Master in Forestry Engineering, Curitiba, Paraná, Brazil - nesi.juliane@ gmail.com \\ ${ }^{4}$ Federal University of Paraná, PhD student in Forest Engineering, Curitiba, Paraná, Brazil - tatiane.1.ho@ gmail.com \\ ${ }^{5}$ State University of the Midwest, Department of Forestry, Irati, Paraná, Brazil - rogerio@unicentro.br \\ Received for publication: 21/05/2019 - Accepted for publication: 04/11/2019
}

\begin{abstract}
Resumo
Arquitetura de copa e morfometria de espécies arbóreas utilizadas na floresta urbana. O planejamento da floresta urbana é necessário para evitar problemas decorrentes da introdução de árvores em espaços urbanos. Dentro do processo de planejamento, como pode ser ocupado o espaço nas calçadas é um item importante para indicar quais espécies podem ser plantadas, de acordo com as características de sua copa. O objetivo do presente trabalho foi analisar índices morfométricos, classificar o padrão de crescimento e determinar a arquitetura de copa de dez espécies plantadas na floresta urbana dos municípios de Curitiba e Pinhais, Paraná, em condições de livre crescimento, sem competição. As espécies amostradas foram caracterizadas pelas variáveis diâmetro à altura do peito, altura total e de copa e raio de copa nos sentidos norte, sul, leste e oeste, as quais auxiliaram na caracterização da morfometria das espécies. Classificou-se a arquitetura de copa conforme modelos estruturais descritos em literatura, a partir de análise visual de imagens de cada árvore. As espécies apresentaram valores maiores que $60 \%$ de proporção de copa. Libidibia ferrea e Koelreuteria paniculata apresentaram a maior amplitude quanto ao formal de copa, dentre elíptica vertical, redonda e elíptica horizontal. Metade das espécies foi enquadrada no modelo de arquitetura de copa do tipo Koriba, duas no modelo Troll e uma em cada um dos tipos D'Attim, Leeuwenberg e Mangenot.

Palavras-chave: modelo de Hallé, padrão de crescimento, formato de copa, índices morfométricos
\end{abstract}

\begin{abstract}
Urban forest planning is necessary to avoid problems coming from the introduction of trees into urban spaces. Within the planning process, how space can be occupied on sidewalks is an important item to indicate which species can be planted according to the canopy characteristics. The objective of this study was to analyze morphometric indexes, to classify the growth pattern and to determine the canopy architecture of ten species planted in the urban forest of the cities Curitiba and Pinhais, Paraná, under conditions of free growth, without competition. The sampled species were characterized by the variables diameter at breast height, total height and canopy height and canopy radius in the north, south, east and west directions, which helped to characterize the morphometry of the species. The canopy architecture was classified according to structural models A $60 \%$ of crown ratio. Libidibia ferrea and Koelreuteria paniculata presented the greatest amplitude regarding the canopy form, between vertical elliptic, round and horizontal elliptic. Half of the species were fit in the canopy architecture model of the Koriba type, two in the Troll model and one in each of the D'Attim, Leeuwenberg and Mangenot types.

Keywords: Hallé's model, growth pattern, canopy shape, morphometric indexes
\end{abstract}

\section{INTRODUCTION}

The purpose of trees in cities has changed over time. Initially the objective was to beautify the streets, houses and squares and, little by little, other environmental, social and economic benefits were noticed and valued. According to Mullaney, Lucke and Trueman (2014), these benefits are not fully available because the growth of trees on sidewalks is limited by root access to water, air and nutrients. These restrictions occur as a consequence of the rapid and disordered growth of most cities, making it difficult to elaborate and execute an adequate planning for the composition and growth of the urban forest (MARTINS et al., 2011; MONTEIRO et al., 2013), which many It is sometimes carried out by professionals with little knowledge, in addition to the scarcity of public policies for the sector.

The set of all vegetation present in the urban perimeter, be they public, private, of native remnants or inserted by man constitute what is meant by urban forest (STRUNK et al., 2016). The urban forest, in its different typologies (parks, squares, residential gardens, afforestation of hunts and forest remnants) can bring several benefits, such as the regulation of the microclimate (LEAL; BIONDI; BATISTA, 2014), the improvement of air quality (VAILSHERY; JAGANMOHAN; NAGENDRA, 2013) and environmental comfort (MARTINI et al., 2013), which help to promote the population's quality of life.

FLORESTA, Curitiba, PR, v. 50, n. 4, p. 1892 - 1901, out/dez 2020.

Carvalho Maria, T. R. B. et.al.

ISSN eletrônico 1982-4688 
In order to be effective in promoting these benefits, the planning of the afforestation of sidewalks aims, among other objectives highlighted by the master plans, to reduce and avoid conflicts between vegetation and urban structures (NASCIMENTO et al., 2017). For that, one must know the development of tree species and choose the one that best fits the available space. This aims to reduce the need for pruning interventions and, consequently, to decrease public spending on the maintenance of urban trees, maximizing their benefits.

Due to the constant anthropic pressure on urban vegetation, it is necessary to carry out studies on the dynamics and development of trees, based on their architecture and growth. From this need, in the 70s, is that the architecture studies of plants began to be consolidated, mainly to predict the growth of a tree, using the branching pattern of its architecture model (COSTA; LONGHI; FÁVERO, 2018 ). Halle (2010), a pioneering author on the topic, after analyzing the meristematic activity of different tree species, characterized 22 architectural models of the plants, through the main axis and the first order branch of the plants to determine the architectural models.

However, although the architecture of the trees is determined by a genotypic factor that characterizes the development of the buds and branches of each species, studies show that trees in the urban environment can be phenotypically influenced by the anthropic environment, and may present a different development from the one presented under open cultivation conditions or forest areas(MACFARLANE; KANE, 2017).

Still in the sense of identifying the growth patterns of the trees, Roman, Bressan and Durlo (2009) state that the morphometric study is an essential factor for the knowledge of the dynamics of the tree shape. Bobrowski and Biondi (2017) corroborate the above and affirm that the morphometric indices act as tools capable of helping the planning of afforestation and its management, due to the knowledge obtained regarding the conformation and natural characteristics of each species.

Thus, knowledge about the behavior of tree growth in the urban environment helps to promote ecosystem services based on adequate planning capable of predicting the canopy size and the direction of growth of a given tree, and what are its space requirements. how is its development, reducing the need for intervention and management (PRETZSCH et al., 2015).

Because of this context, the objectives of this study were to analyze the development, the morphometric dimensional relationships and the canopy architecture of ten tree species found in different types of urban forest in the municipalities of Curitiba and Pinhais, Paraná.

\section{MATERIAL AND METHODS}

\section{Study area}

The present study was carried out in the municipalities of Curitiba (between coordinates $25^{\circ} 25^{\prime} 40$ " $\mathrm{S}$ and $49^{\circ} 16^{\prime} 23^{\prime \prime} \mathrm{W}$ ) and Pinhais (between coordinates $25^{\circ} 26^{\prime} 41^{\prime \prime} \mathrm{S}$ and $49^{\circ} 11^{\prime} 33^{\prime \prime} \mathrm{W}$ ), respectively the state capital and the metropolitan region of the State of Paraná (IPARDES, 2019). The climate of the region is of the Cfb type according to the Köppen-Geiger classification, with annual average temperature of $17{ }^{\circ} \mathrm{C}$, relative humidity of around $85 \%$, sum of annual precipitation between 1,300 and $1,500 \mathrm{~mm}$ and average altitude of 934.0 meters (MAACK, 2017). Originally the regional vegetation was composed by areas of mixed ombrophilous forest (FOM) and natural fields (IPARDES, 2017).

The trees considered adequate for data collection were present in three types of public urban forest (afforestation of sidewalks, parks and squares), in different conditions of construction sites, but as long as they met the prerequisite of not showing signs of interference in the development of the trees. by pruning or physical barriers, such as poles and walls.

\section{Methodological procedures}

Ten species commonly found in the urban forest of the metropolitan region of Curitiba (Bauhinia variegata L., Libidibia ferrea (Mart. Ex Tul.) LPQueiroz, Handroanthus albus (Cham.) Mattos, Handroanthus chrysotrichus (Mart. Ex DC.) Mattos) were selected, Handroanthus heptaphyllus (Vell.) Mattos, Koelreuteria paniculata Laxm., Lafoensia pacari A.St.Hil., Liquidambar styraciflua L., Platanus x acerifolia (Aiton) Villd. And Cerasus campanulata (Maxim.) AN Vassiljeva). These species were chosen according to the availability of 10 trees of each species, with no signs of pruning and without intertwined canopies, so that the full development of the canopy and its characteristic architecture could be evaluated.

The data collection was carried out in the urban area of the municipalities, from May to July 2018. The variables collected in the field were species, canopy projection rays to the north, south, east and west directions, diameter at breast height $(\mathrm{DBH})$, total height $(\mathrm{Ht})$ and canopy length $(\mathrm{Cc})$. All specimens were photographed in the north-south and east-west direction for further analysis and classification of each specimen in the architectural growth models described by Hallé (2010).

To describe the spatial conformation of each species, based on quantitative data, five morphometric indices were determined to express interdimensional relations in each tree (BOBROWSKI; BIONDI, 2017): 
canopy proportion (which can be an indication of the quality of the benefits offered in virtue of the amount of green leaf mass), degree of slimness (used to prioritize actions to assess the susceptibility of trees to fall), salience index (this is able to assist in planning the most appropriate spacing for each species for maximum growth and offering benefits ), coverage index and formal canopy index (used to numerically express the aesthetic characteristic of the canopy shape of trees and their alterations). For these indices, there are no predefined minimum and maximum values because this can vary depending on the dimensional characteristics of each species and the conditions where the trees are planted (grouped or isolated).

From the minimum, average and maximum values of the formal canopy index, the canopy conformation classification was performed (TABLE 1), following the class limits proposed by Bobrowski and Biondi (2017), in order to assess the variation that could exist for a given species in urban growth conditions. Therefore, we considered the canopy conformation classes of the vertical columnar, vertical elliptical, rounded, horizontal elliptical and horizontal columnar types.

To determine the canopy architecture characteristic of each species, the growth patterns of the main axis (codominant or dominant leader), of the secondary axes (plagiotropic, orthotropic or mixed) and the apical characteristic of the branches (descendants, horizontal or ascending). From these categorizations it was possible to classify the trees according to the 22 architectural models proposed by Halle (2010), shown in Figure 1

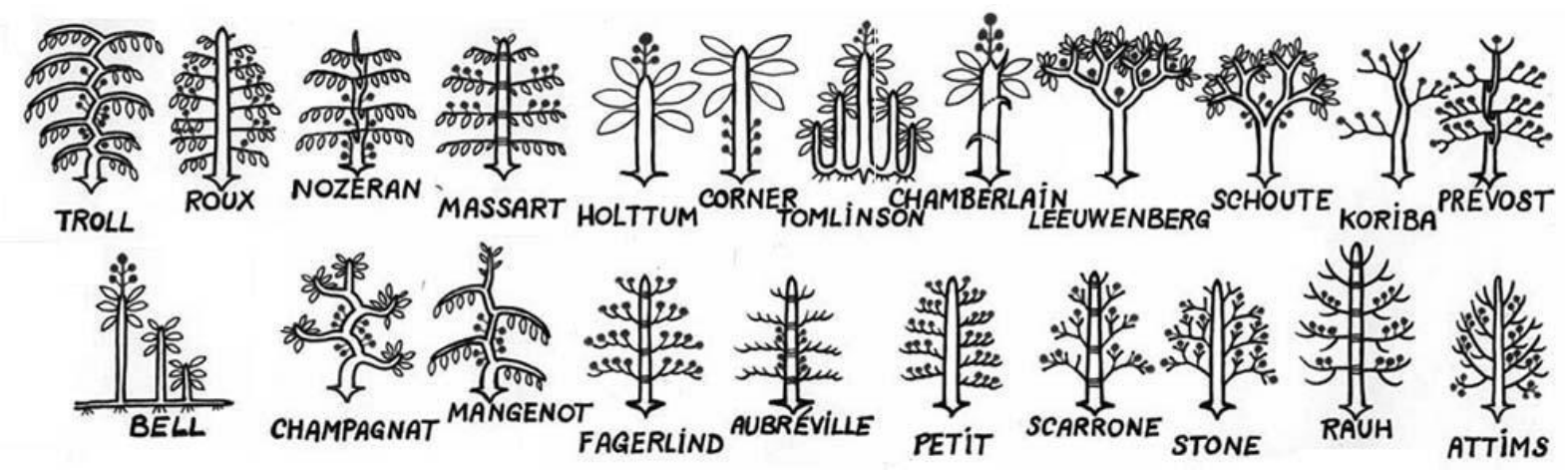

Figura 1. Modelos de arquitetura de Hallé (2010).

Figure 1. Architecture models of Hallé (2010).

The architectural pattern of the species was defined when $60 \%$ or more of the trees of the species were classified in the same model of canopy architecture. For each tree, two canopy images were evaluated in an orthogonal direction, comparing the canopy diameter measured in the north-south direction with that measured in the east-west direction, in order to determine the existence of dimensional similarity between the two evaluation axes of the photographs. To validate this classification, randomized block design was used, where the treatments corresponded to each measurement axis, with each tree corresponding to a block. The trees were considered blocks due to the spatial variability of the soil and the environmental conditions that could exist between the selected trees.

The data was compiled in an Excel® 2010 spreadsheet and the statistical analysis was performed using the Assistat ${ }^{\circledR}$ software version 7.

\section{RESULTS}

For all the variables of interest, the species Lafoensia pacari was the one that presented the lowest results for the variation coefficient (TABLE 1), while the largest, except in DAP, were observed for Platanus $x$ acerifolia.

Tabela 1. Variabilidade das variáveis dendrométricas obtidas para o cálculo dos índices morfométricos Table 1. Variability of dendrometric variables obtained for the calculation of morphometric indices

\begin{tabular}{ccccccccc}
\hline \multirow{2}{*}{ Variables } & \multicolumn{4}{c}{ Bauhinia variegata } & \multicolumn{3}{c}{ Libidibia ferrea } \\
\cline { 2 - 8 } & Min & Ave & Max & CV\% & Min & Ave & Max & CV\% \\
\hline Cc (m) & 3,00 & 4,55 & 6,50 & 24,54 & 2,00 & 4,55 & 10,00 & 46,75 \\
Ht (m) & 4,50 & 6,35 & 8,00 & 18,94 & 4,50 & 6,60 & 12,50 & 34,77 \\
DAP (m) & 10,94 & 21,60 & 35,97 & 38,06 & 9,87 & 14,74 & 38,52 & 58,09 \\
DcNS (m) & 4,43 & $6,63 \mathrm{a}$ & 8,25 & 21,25 & 2,75 & $4,28 \mathrm{a}$ & 9,00 & 42,68 \\
DcLO (m) & 4,39 & $6,86 \mathrm{a}$ & 9,80 & 25,48 & 2,93 & $4,42 \mathrm{a}$ & 9,60 & 44,42 \\
\hline Variables & \multicolumn{4}{c}{ Handroanthus albus } & \multicolumn{3}{c}{ Handroanthus chrysotrichus } \\
\hline
\end{tabular}

FLORESTA, Curitiba, PR, v. 50, n. 4, p. 1892 - 1901, out/dez 2020.

Carvalho Maria, T. R. B. et.al.

ISSN eletrônico 1982-4688 


\begin{tabular}{|c|c|c|c|c|c|c|c|c|}
\hline & Min & Ave & Max & CV\% & Min & Ave & Max & CV\% \\
\hline $\mathrm{Cc}(\mathrm{m})$ & 3,00 & 5,80 & 9,00 & 35,01 & 2,00 & 6,80 & 11,00 & 45,09 \\
\hline $\mathrm{Ht}(\mathrm{m})$ & 6,00 & 8,65 & 11,00 & 23,45 & 4,00 & 9,85 & 16,50 & 41,24 \\
\hline $\mathrm{DAP}(\mathrm{m})$ & 16,55 & 29,48 & 50,29 & 28,66 & 8,28 & 16,84 & 26,74 & 38,96 \\
\hline $\operatorname{DcNS}(\mathrm{m})$ & 4,84 & $7,42 \mathrm{a}$ & 11,51 & 23,21 & 3,60 & $5,55 \mathrm{a}$ & 7,46 & 27,48 \\
\hline $\operatorname{DcLO}(\mathrm{m})$ & 4,63 & $7,35 \mathrm{a}$ & 11,57 & 24,53 & 2,90 & $5,98 \mathrm{a}$ & 9,84 & 39,93 \\
\hline \multirow{2}{*}{ Variables } & \multicolumn{4}{|c|}{ Handroanthus heptaphyllus } & \multicolumn{4}{|c|}{ Koelreuteria paniculata } \\
\hline & Min & Ave & Max & CV\% & Min & Ave & Max & CV\% \\
\hline $\mathrm{Cc}(\mathrm{m})$ & 3,50 & 6,05 & 10,00 & 34,06 & 4,50 & 5,60 & 7,00 & 14,46 \\
\hline $\mathrm{Ht}(\mathrm{m})$ & 4,50 & 8,20 & 15,00 & 37,72 & 7,00 & 9,05 & 11,50 & 16,77 \\
\hline $\mathrm{DAP}(\mathrm{m})$ & 9,55 & 18,49 & 41,38 & 50,22 & 12,41 & 21,82 & 35,01 & 37,02 \\
\hline DcNS (m) & 3,76 & $6,31 \mathrm{a}$ & 11,45 & 33,73 & 5,39 & $7,72 \mathrm{a}$ & 13,39 & 31,48 \\
\hline $\operatorname{DcLO}(\mathrm{m})$ & 3,92 & $6,41 \mathrm{a}$ & 12,20 & 37,17 & 5,52 & $7,86 \mathrm{a}$ & 12,26 & 30,59 \\
\hline \multirow{2}{*}{ Variáveis } & \multicolumn{4}{|c|}{ Lafoensia pacari } & \multicolumn{4}{|c|}{ Liquidambar styraciflua } \\
\hline & Min & Ave & Max & CV\% & Min & Ave & Max & CV\% \\
\hline $\mathrm{Cc}(\mathrm{m})$ & 6,00 & 7,55 & 9,00 & 13,41 & 3,00 & 5,50 & 9,50 & 32,64 \\
\hline $\mathrm{Ht}(\mathrm{m})$ & 7,00 & 9,20 & 10,50 & 12,34 & 5,00 & 7,70 & 11,50 & 23,55 \\
\hline $\mathrm{DAP}(\mathrm{m})$ & 16,23 & 24,21 & 32,00 & 21,31 & 9,07 & 20,16 & 34,06 & 44,65 \\
\hline DcNS (m) & 4,80 & $6,42 \mathrm{a}$ & 7,70 & 13,91 & 3,98 & $6,74 a$ & 10,07 & 28,64 \\
\hline $\operatorname{DcLO}(\mathrm{m})$ & 4,30 & $6,23 \mathrm{a}$ & 7,90 & 16,18 & 3,65 & $6,54 \mathrm{a}$ & 8,53 & 25,89 \\
\hline \multirow{2}{*}{ Variables } & \multicolumn{4}{|c|}{ Platanus $\mathrm{x}$ acerifolia } & \multicolumn{4}{|c|}{ Cerasus campanulata } \\
\hline & Min & Med & Max & CV\% & Min & Med & Max & CV\% \\
\hline $\mathrm{Cc}(\mathrm{m})$ & 2,50 & 6,45 & 15,50 & 60,65 & 2,50 & 5,75 & 10,00 & 44,01 \\
\hline $\mathrm{Ht}(\mathrm{m})$ & 5,50 & 10,15 & 19,00 & 39,28 & 5,50 & 8,35 & 13,50 & 34,69 \\
\hline $\mathrm{DAP}(\mathrm{m})$ & 7,00 & 19,96 & 47,75 & 70,54 & 10,50 & 19,39 & 41,06 & 52,07 \\
\hline $\operatorname{DcNS}(\mathrm{m})$ & 3,07 & $7,92 \mathrm{a}$ & 17,00 & 58,06 & 4,00 & $6,20 \mathrm{a}$ & 10,70 & 34,73 \\
\hline $\operatorname{DcLO}(\mathrm{m})$ & 3,68 & $8,05 \mathrm{a}$ & 17,46 & 51,24 & 3,20 & $6,32 \mathrm{a}$ & 10,40 & 35,09 \\
\hline
\end{tabular}

Legend: MIN (minimum value of the variable); AVE (mean value of the variable); MAX (maximum variable value); CV\% (percentage variation coefficient); Cc (canopy length); Ht (total height); DBH (diameter at breast height); DcNS (canopy diameter in the north and south direction); DcLO (canopy diameter in east and west direction).

It was found that there was no significant difference in the direction of measuring the canopy diameter (Table 2), as for each species evaluated the length of the compared south-east and west-west axes were shown to be approximate. In this way, any evaluation looking into characterizing the architectural model can be used for the trees evaluated, as there is symmetry in the horizontal projection of the canopy.

Tabela 2. Análise de variância, por espécie, para o comprimento dos eixos de projeção da copa nos sentidos notesul e leste-oeste.

Table 2. Analysis of variance, by species, for the length of the canopy projection axes in the north-south and eastwest directions.

\begin{tabular}{|c|c|c|c|c|c|c|c|}
\hline \multicolumn{4}{|c|}{ Bauhinia variegata } & \multicolumn{4}{|c|}{ Libidibia ferrea } \\
\hline FV & GL & QM & p-valor & FV & GL & $\mathbf{Q M}$ & p-valor \\
\hline Blocks & 9 & 6,23 & $1,34^{-4}$ & Blocks & 9 & 37,11 & $6,09^{-6}$ \\
\hline Axis & 1 & 0,21 & 0,47 & Axis & 1 & 0,08 & 0,79 \\
\hline Residue & 9 & 0,37 & & Residue & 9 & 1,06 & \\
\hline \multicolumn{4}{|c|}{ Handroanthus albus } & \multicolumn{4}{|c|}{ Handroanthus chrysotrichus } \\
\hline FV & GL & QM & p-valor & FV & GL & QM & p-valor \\
\hline Blocks & 9 & 6,13 & $2,85^{-7}$ & Blocks & 9 & 7,35 & $7,49^{-4}$ \\
\hline Axis & 1 & 0,02 & 0,63 & Axis & 1 & 0,91 & 0,28 \\
\hline Residue & 9 & 0,09 & & Residue & 9 & 0,68 & \\
\hline \multicolumn{4}{|c|}{ Handroanthus heptaphyllus } & \multicolumn{4}{|c|}{ Koelreuteria paniculata } \\
\hline FV & GL & QM & p-valor & FV & GL & $\mathbf{Q M}$ & p-valor \\
\hline Blocks & 9 & 10,05 & $4,36^{-7}$ & Blocks & 9 & 11,27 & $1,78^{-5}$ \\
\hline Axis & 1 & 0,05 & 0,57 & Axis & 1 & 0,09 & 0,64 \\
\hline Residue & 9 & 0,16 & & Residue & 9 & 0,41 & \\
\hline \multicolumn{4}{|c|}{ Lafoensia pacari } & \multicolumn{4}{|c|}{ Liquidambar styraciflua } \\
\hline
\end{tabular}

FLORESTA, Curitiba, PR, v. 50, n. 4, p. 1892 - 1901, out/dez 2020.

Carvalho Maria, T. R. B. et.al.

ISSN eletrônico 1982-4688 


\begin{tabular}{lccc|lccc}
\hline FV & GL & QM & p-valor & FV & GL & QM & p-valor \\
\hline Blocks & 9 & 7,15 & $1,34^{-8}$ & Blocks & 9 & 1,74 & $3,72^{-5}$ \\
Axis & 1 & 0,09 & 0,19 & Axis & 1 & 0,18 & 0,16 \\
Residue & 9 & 0,05 & & Residue & 9 & 0,08 \\
\hline \multicolumn{3}{c}{ Platanus x acerifolia } & \multicolumn{4}{c}{ Cerasus campanulata } \\
\hline FV & GL & QM & p-valor & FV & GL & QM & p-valor \\
\hline Blocks & 9 & 9,18 & $2,86^{-5}$ & Blocks & 9 & 4,85 & $2,46^{-5}$ \\
Axis & 1 & 0,07 & 0,67 & Axis & 1 & 0,26 & 0,28 \\
Residue & 9 & 0,38 & & Residue & 9 & 0,19 & \\
\hline
\end{tabular}

Regarding the morphometric indices, all species presented more than $60 \%$ of canopy proportion. This result indicates that the trees, in general, present most of their height composed by the green mass of branches and leaves and not by the trunk(Table 4).

Tabela 3. Variabilidade dos índices morfométricos obtidos para as espécies avaliadas Table 3. Variability of the morphometric indices obtained for the evaluated species

\begin{tabular}{|c|c|c|c|c|c|c|c|c|}
\hline \multirow{2}{*}{ Morphometric index } & \multicolumn{4}{|c|}{ Bauhinia variegata } & \multicolumn{4}{|c|}{ Libidibia ferrea } \\
\hline & Min & Ave & $\operatorname{Max}$ & CV\% & Min & Ave & Max & CV\% \\
\hline Canopy proportion & 47,37 & 70,95 & 85,71 & 17,20 & 45,45 & 59,85 & 81,58 & 21,25 \\
\hline Degree of slimness & 22,02 & 43,79 & 70,42 & 36,70 & 29,32 & 59,35 & 78,54 & 27,32 \\
\hline Salience Index & 13,56 & 17,97 & 24,39 & 7,20 & 15,18 & 21,82 & 30,87 & 24,47 \\
\hline Coverage Index & 0,30 & 0,44 & 0,62 & 4,51 & 0,27 & 0,39 & 0,62 & 32,18 \\
\hline Canopy format & 0,41 & 0,63 & 0,85 & 5,41 & 0,40 & 0,68 & 1,25 & 41,71 \\
\hline Canopy shaping & EV & EV & EV & & EV & $\mathrm{EV}$ & $\mathrm{EH}$ & \\
\hline \multirow{2}{*}{ Morphometric index } & \multicolumn{4}{|c|}{ Handroanthus albus } & \multicolumn{4}{|c|}{ Handroanthus chrysotrichus } \\
\hline & Min & Ave & Max & CV\% & Min & Ave & Max & CV\% \\
\hline Canopy proportion & 46,15 & 65,66 & 81,82 & 15,33 & 50,00 & 67,83 & 83,33 & 13,99 \\
\hline Degree of slimness & 21,67 & 30,34 & 39,27 & 23,42 & 46,75 & 58,31 & 71,99 & 13,80 \\
\hline Salience Index & 11,47 & 12,69 & 14,30 & 7,46 & 15,10 & 17,64 & 21,93 & 12,07 \\
\hline Coverage Index & 0,31 & 0,44 & 0,57 & 19,87 & 0,23 & 0,31 & 0,45 & 21,75 \\
\hline Canopy format & 0,47 & 0,67 & 0,86 & 20,77 & 0,33 & 0,47 & 0,91 & 35,56 \\
\hline Canopy shaping & $\mathrm{EV}$ & $\mathrm{EV}$ & $\mathrm{EV}$ & & EV & $\mathrm{EV}$ & RED & \\
\hline \multirow[t]{2}{*}{ Morphometric index } & \multicolumn{4}{|c|}{ Handroanthus heptaphyllus } & \multicolumn{4}{|c|}{ Koelreuteria paniculata } \\
\hline & Min & Ave & Max & CV\% & Min & Ave & Max & CV\% \\
\hline Canopy proportion & 63,64 & 74,62 & 94,12 & 11,01 & 50,00 & 62,55 & 71,43 & 11,94 \\
\hline Degree of slimness & 36,25 & 46,82 & 76,16 & 24,43 & 31,42 & 45,24 & 73,30 & 30,65 \\
\hline Salience Index & 14,29 & 18,26 & 26,32 & 19,60 & 13,91 & 18,50 & 24,00 & 16,02 \\
\hline Coverage Index & 0,34 & 0,40 & 0,55 & 15,62 & 0,29 & 0,43 & 0,56 & 20,28 \\
\hline Canopy format & 0,42 & 0,54 & 0,76 & 17,78 & 0,48 & 0,70 & 1,10 & 27,44 \\
\hline Canopy shaping & EV & $\mathrm{EV}$ & $\mathrm{EV}$ & & $\mathrm{EV}$ & $\mathrm{EV}$ & $\mathrm{EH}$ & \\
\hline \multirow{2}{*}{ Morphometric index } & \multicolumn{4}{|c|}{ Lafoensia pacari } & \multicolumn{4}{|c|}{ Liquidambar styraciflua } \\
\hline & Min & Ave & Max & CV\% & Min & Ave & Max & CV\% \\
\hline Canopy proportion & 44,44 & 67,14 & 80,00 & 14,63 & 75,00 & 82,07 & 88,24 & 5,11 \\
\hline Degree of slimness & 32,45 & 47,84 & 59,84 & 18,76 & 33,91 & 39,15 & 53,20 & 18,85 \\
\hline Salience Index & 11,21 & 15,58 & 21,88 & 23,27 & 11,51 & 13,31 & 16,60 & 12,23 \\
\hline Coverage Index & 0,28 & 0,33 & 0,39 & 12,21 & 0,27 & 0,34 & 0,40 & 9,84 \\
\hline Canopy format & 0,38 & 0,50 & 0,71 & 21,64 & 0,31 & 0,42 & 0,53 & 13,85 \\
\hline Canopy shaping & EV & EV & EV & & EV & $\mathrm{EV}$ & $\mathrm{EV}$ & \\
\hline \multirow{2}{*}{ Morphometric index } & \multicolumn{4}{|c|}{ Platanus $x$ acerifolia } & \multicolumn{4}{|c|}{ Cerasus campanulata } \\
\hline & Min & Ave & $\operatorname{Max}$ & CV\% & Min & Ave & $\operatorname{Max}$ & $\mathrm{CV} \%$ \\
\hline Canopy proportion & 45,45 & 67,02 & 82,35 & 19,42 & 60,00 & 71,43 & 90,00 & 13,74 \\
\hline Degree of slimness & 32,88 & 45,85 & 57,12 & 17,39 & 16,68 & 34,48 & 68,54 & 49,54 \\
\hline Salience Index & 11,39 & 17,13 & 19,72 & 14,09 & 8,29 & 18,36 & 38,82 & 54,08 \\
\hline Coverage Index & 0,33 & 0,38 & 0,47 & 14,55 & 0,31 & 0,54 & 0,66 & 20,99 \\
\hline Canopy format & 0,41 & 0,59 & 1,01 & 28,73 & 0,42 & 0,78 & 1,04 & 28,99 \\
\hline Canopy shaping & $\mathrm{EV}$ & $\mathrm{EV}$ & RED & & EV & $\mathrm{EV}$ & RED & \\
\hline
\end{tabular}

Caption: Min: minimum. Ave: Average. Max: maximum. CV\%: coefficient of variation expressed as a percentage. EV: Vertical elliptical. EH: Horizontal elliptical. RED: round. 
Regarding the degree of slimness, the species that presented the highest average values were Libidibia ferrea (59.35) and Handroanthus chrysotrichus (58.31). As for the salience index, the species with the lowest average value was Handroanthus albus (12.69) and the one with the highest average value was Libidibia ferrea (21.82). For the coverage index, the average values ranged between 0.31 (Handroanthus chrysotrichus) and 0.54 (Cerasus campanulata).

Handroanthus chrysotrichus had an average canopy format value of 0.47 and the conformation of the canopy classified as vertical elliptical. The Libidibia ferrea and Koelreuteria paniculata trees, on the other hand, showed the greatest amplitude regarding the canopy format, for demonstrating canopy conformation changing between vertical, round and horizontal elliptical (Figure 2).
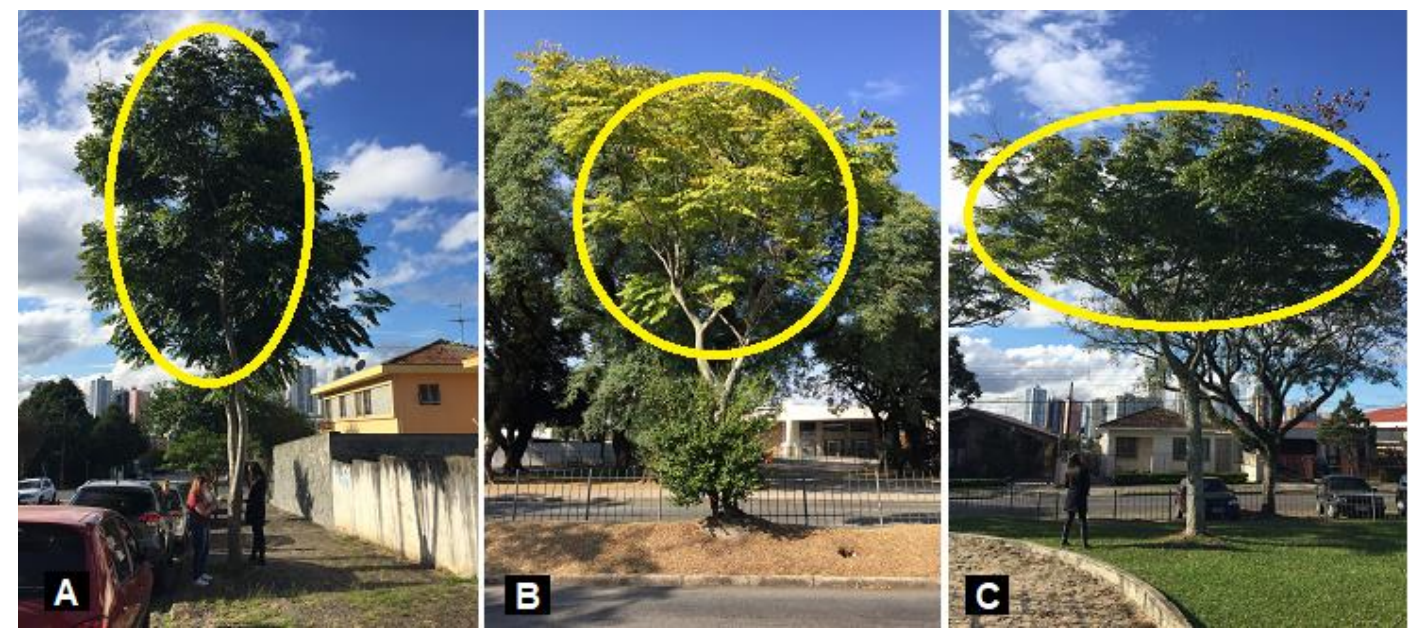

Figura 2. Diferentes amplitudes de conformação de copa encontradas para Koelreuteria paniculata: elíptica vertical (A), redonda (B) e elíptica horizontal (C)

Figure 2. Different canopy-shape amplitudes found for Koelreuteria paniculata: vertical elliptic (A), round (B) and horizontal elliptical (C)

The vertical elliptical conformation was found as a standard for the species Bauhinia variegata, Handroanthus albus, Handroanthus heptaphyllus, Lafoensia pacari and Liquidambar styraciflua, in 100\% of the trees evaluated.

Regarding the classification of species in the architectural models of Halle (2010), five models were observed that best classified the species evaluated (Table 5).

Tabela 5. Distribuição percentual das árvores de cada espécie em relação aos modelos de Hallé (2010)

Table 5. Percentage distribution of the trees of each species in relation to the models of Hallé (2010)

\begin{tabular}{|c|c|c|c|c|c|}
\hline \multirow{2}{*}{ Species } & \multicolumn{5}{|c|}{ Architectural model } \\
\hline & D'Attim & Leeuwenberg & Koriba & Troll & Mangenot \\
\hline Bauhinia variegata & & & 70 & 30 & \\
\hline Libidibia férrea & & 60 & 40 & & \\
\hline Handroanthus albus & & & & 10 & 90 \\
\hline Handroanthus chrysotrichus & & & & 100 & \\
\hline Handroanthus heptaphyllus & & & 80 & 20 & \\
\hline Koelreuteria paniculata & & 30 & 70 & & \\
\hline Lafoensia pacari & & & 10 & 80 & 10 \\
\hline Liquidambar styraciflua & 100 & & & & \\
\hline Platanus $x$ acerifolia & & & 100 & & \\
\hline Cerasus campanulata & & & 90 & 10 & \\
\hline
\end{tabular}

The species Bauhinia variegata, Handroanthus heptaphyllus, Koelreuteria paniculata, Platanus $x$ acerifolia and Cerasus campanulata (Figure 3), presented more than $70 \%$ of the specimens classified in the Koriba architectural model, whereas for Platanus x acerifolia, $100 \%$ of their specimens were observed in that model..

FLORESTA, Curitiba, PR, v. 50, n. 4, p. 1892 - 1901, out/dez 2020.

Carvalho Maria, T. R. B. et.al.

ISSN eletrônico 1982-4688 


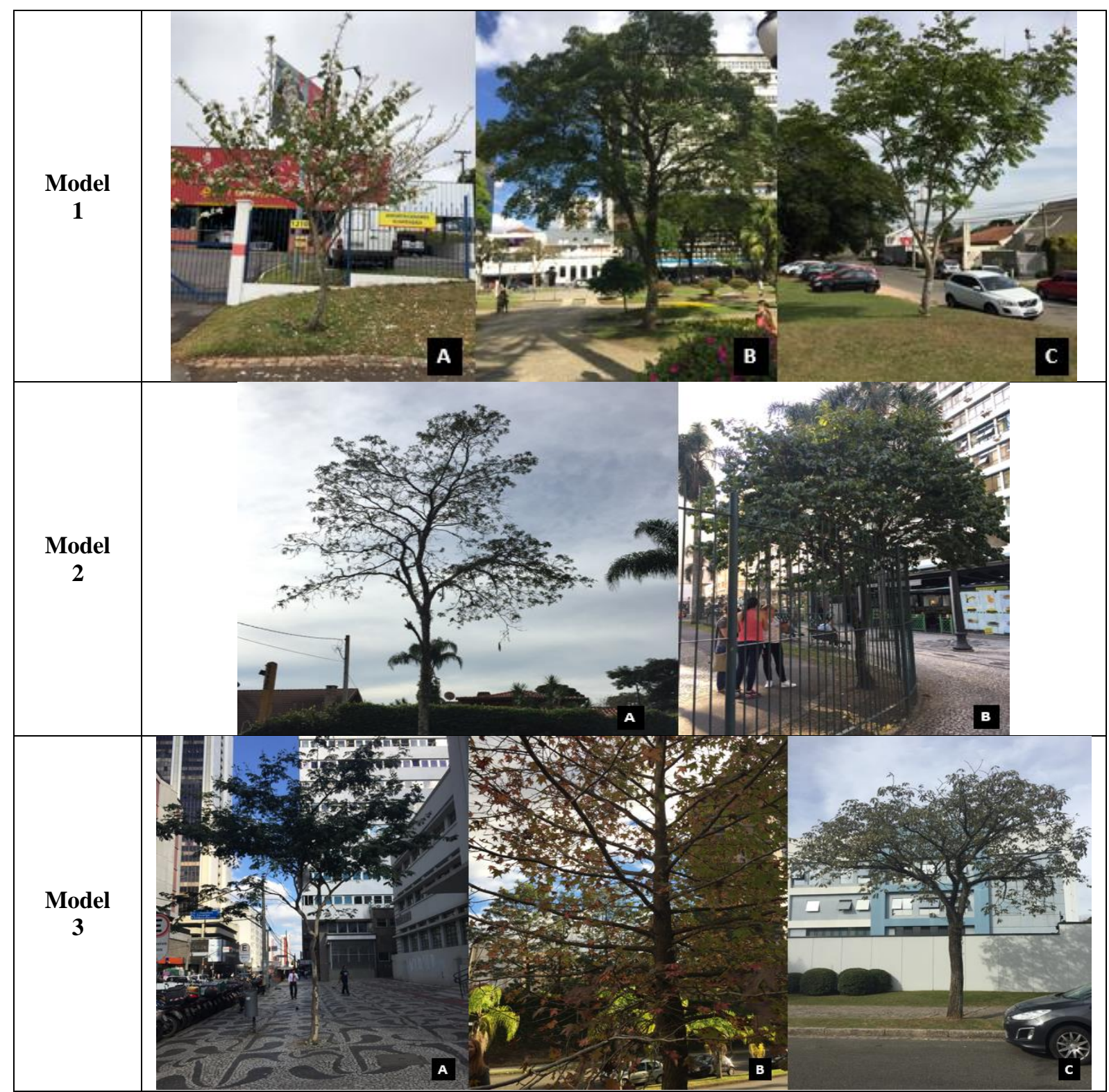

Figura 3. Exemplos do modelo de arquitetura de copa do tipo Koriba, em Bauhinia variegata (Modelo 1A), Handroanthus heptaphyllus (Modelo 1B), Koelreuteria paniculata (Modelo 1C), do tipo Troll em Handroanthus chrystrichus (Modelo 2A) e em Lafoensia pacari (Modelo 2B), do tipo de Leeuwenberg em Libidibia ferrea (Modelo 3A), de d'Attim em Liquidambar styraciflua (Modelo 3B) e de Mangenot em Handroanthus albus (Modelo 3C)

Figure 3. Examples of Koriba type canopy architecture model in Bauhinia variegata (Model 1A), Handroanthus heptaphyllus (Model 1B), Koelreuteria paniculata (Model 1C), Troll type in Handroanthus chrystrichus (Model 2A) and Lafoensia pacari (Model 2B), Leeuwenberg type in Libidibia ferrea (Model 3A), d'Attim in Liquidambar styraciflua (Model 3B) and Mangenot in Handroanthus albus (Model 3C)

For the species Handroanthus chrysotrichus and Lafoensia pacari, $100 \%$ and $80 \%$ of the specimens, respectively, were classified as Troll's architectural model (Figure 4).

Leeuwenberg's architectural model corresponded to the classification of $60 \%$ of Libidibia ferrea (Figure 5A), whereas for D'attim (Figure 5B) and Mangenot (Figure 5C), more examples of Liquidambar styraciflua (100\%) were observed and Handroanthus albus (90\%), respectively (Table 6). 


\section{DISCUSSION}

Under ideal experimental conditions, in a controlled environment, the variation in the dendrometric data of the trees, given by the variation coefficient, should not exceed 10\% (BOBROWSKI; BIONDI, 2017). However, considering that the urban area has heterogeneous characteristics and diversified relation between infrastructure and trees, there is no way to carry out environmental and man-made control. Because of this, coefficients of variation $(\mathrm{CV} \%)$ were observed higher than the aforementioned limit for controlled ideal experimental conditions. However, considering that the trees evaluated in this study did not show signs of interference to control growth and safety, through pruning, the values of the coefficient of variation may be closely associated with the size and age of the same species.

When comparing the species with the lowest and highest $\mathrm{CV} \%$, the results showed that the species Platanus $x$ acerifolia was the one that presented the greatest amplitude among the individuals of smaller and larger size. This result indicates that the species probably presents individuals with different planting ages, thus ensuring better sustainability of the planting composition with species in the urban environment. This variation was also verified in recent studies with other species in the same city (BOBROWSKI; LIMA NETO; BIONDI, 2013, BOBROWSKI; BIONDI, 2017).

It is considered that most of the benefits provided by the urban forest are correlated with the size of the canopy (TROXEL et al., 2013), the species with the highest average values of canopy proportion, Cerasus campanulata (71.43\%), Liquidambar styraciflua (82.07\%) and Handroanthus heptaphyllus (74.62\%), are the ones that can enable a greater offer of benefits, among the studied species. According to Gonçalves et al. (2010) the crowns of the trees are greatly influenced, in size and shape, by the amount of solar incidence, while the growth of the tree base is more related to the mechanical resistance exerted on the plant. The number of leaves can also be seen as one of the factors that indicate the best offer of benefits, since they result in higher rates of evapotranspiration of trees in the urban forest.

Regarding the degree of slimness, Bobrowski and Biondi (2017) found similar values for Handroanthus chrysotrichus (53.59). However, comparing to the study by Sanquetta et al. (2013) it is possible to observe that the lowest degree of average slimness for tree species in a forest fragment located in the same phytogeographic region was equal to 65 , a value higher than the maximum found for the trees in the present study $(59,35)$. Bobrowski and Biondi (2017) justify that the values in the degree of slimness of trees in urban areas are lower than in natural forests because the competition for space and resources in the urban area is less, so there is a greater investment of growth in diameter than in height.

As for the salience index, the maximum values found in this study are lower than those found by Roman, Bressan and Durelo (2009) in an area of remaining forest formation, where the value in the urban area was 21.8 and in the vegetation area remaining was 24.7. MacFarlane and Kane (2017) justify that the level of overhang tends to be higher in forest formations due to the greater shading provided by the agglomeration of trees in these environments, which induces a greater "thinning" of the trunk and "widening" of the canopy as a strategy of greater light absorption by trees.

Unlike the one found by Bobrowski and Biondi (2017), the Handroanthus chrysotrichus species presented a vertical and formal elliptical conformation of 1.58 medium canopy, showing itself as a suitable species for narrow sidewalks, with less horizontal space available. The canopy format is shown as an important characteristic to be understood for the insertion of trees in the urban environment, in view of the better adaptation of certain species to places with space limitations, vertical or horizontal, for the growth of the plant, causing the pace of interventions that the tree will receive during its life cycle.

In this study, only the d'Attim model, which has characteristics of monopodial branching, was represented in 100\% of Liquidambar styraciflua individuals. This indicates that the species may be more susceptible to damage by pruning, as maintenance practices could cause deformations in the architecture of the species (SANTOS; TEIXEIRA, 2001). However, this is an architectural model that is expected in urban trees because there is a single leading branch with branches with a diameter less than half the diameter of the portion of the trunk where they are inserted. Because of this, this model limits the appearance of structural defects such as the crack with bark included in codominant trunks.

Koriba's model was the one with the lowest frequency in species from the Subtropical Seasonal Forest, with only two species being classified in this model, among them Handroanthus heptaphyllus (COSTA; LONGHI; FÁVERO, 2018). However, in the afforestation of sidewalks this was the model that grouped the largest number of species, being that Handroanthus heptaphyllus, Platanus $x$ acerifolia and Cerasus campanulata presented 80\% or more of the individuals in this classification. This model is described as having an orthotropic trunk and branches, which indicates that the formation of the canopy tends to have greater vertical growth (COSTA; LONGHI, 2018). These characteristics allow less maintenance by canopy pruning for trees of this species, however

FLORESTA, Curitiba, PR, v. 50, n. 4, p. 1892 - 1901, out/dez 2020.

Carvalho Maria, T. R. B. et.al.

ISSN eletrônico 1982-4688

DOI: $10.5380 /$ rf.v50 i4. 66995 
it is worth emphasizing the need for ample vertical space for these species so that they do not suffer from lowering pruning.

The individuals of Handroanthus chrysotrichus were fully classified in the Troll model. This model is characterized by presenting mixed axes, with the trunk with orthotropic growth and dominant axis, branches with plagiotropic growth without apical characterization of the determined branches (COSTA; LONGHI; FÁVERO, 2018). Trees of this model have the advantage of easy recovery of canopy compliance after pruning, however the irregular growth format requires care with the planting site so that interventions are less incident.

The species Bauhinia variegata, Koelreuteria paniculata and Caesalpinia leiostachya did not have the classification of the model determined, as they did not present enough percentage to group them in a single model (more than $70 \%$ ).

None of the architectural models observed can be harmful to the safety of people and properties because they predispose to greater risks. However, trees with the d'Attim model may have a greater need for pruning interventions to control the growth and size of branches in areas with a greater number of structures and possible conflict.

\section{CONCLUSIONS}

- The lack of difference in projection between the canopy axes of the species was important to ensure the adequacy of the analysis of the models of canopy architecture;

- All species had an average canopy formal value of less than 1, which implies that, for most of the trees evaluated, the canopies tend to have vertical elliptical conformation, ideal for environments with lateral canopy projection limitations;

- Five architectural models were observed in the representation of the species evaluated: D'Attim, Leeuwenber, Troll, Mangenot and Koriba, the last being the most frequent.

\section{REFERENCES}

BOBROWSKI, R.; BIONDI, D. Morfometria de espécies florestais plantadas nas calçadas. Revista da Sociedade Brasileira de Arborização Urbana. Piracicaba, v. 12, n.1, p. 01-16, 2017.

BOBROWSKI, R.; LIMA NETO, E. M.; BIONDI, D. Alterações na arquitetura típica de Tipuana tipu (Benth.) O. Kuntze na arborização de ruas de Curitiba, Paraná. Ciência Florestal, Santa Maria, v. 23, n. 3, p. 281 - $289,2013$.

COSTA, M. P.; LONGHI, S. J.; FAVERO, A. A. Arquitetura e estrutura vertical da comunidade arbórea de uma floresta estacional subtropical. Ciência Florestal, Santa Maria, v. 28, n. 4, p. 1443 - 1454, 2018.

COSTA, M. P.; LONGHI, S. J. Modelos arquitetônicos para as espécies arbóreas de uma floresta estacional subtropical no Rio Grande do Sul. Ciência Florestal, Santa Maria, v. 28, n. 4, p. 1418 - 1430, 2018.

GONÇALVES, D. A.; SCHWARTZ, G.; POKORNY, B.; VAN ELDIK, T. O uso da classificação de copa de Dawkins como indicador do comportamento ecológico de espécies arbóreas tropicais. Floresta, Curitiba, Paraná, v. 40, n. 1, p. $175-182,2010$.

HALlÉ, F. Arquitectura de los árboles. Boletín de la Sociedad Botánica de México. Distrito Federal, v.45, n. 34, p.405-418, 2010.

INSTITUTO PARANAENSE DE DESENVOLVIMENTO ECONÔMICO E SOCIAL - IPARDES. Indicadores de desenvolvimento sustentável - 2017. Dimensão Ambiental 1. Disponível em: $<\mathrm{http}: / / \mathrm{www}$. ipardes.gov.br/index.php?pg_conteudo=1\&sistemas=1\&cod_sistema=5\&grupo_indic=3>. Acesso em: 08/07/2018.

INSTITUTO PARANAENSE DE DESENVOLVIMENTO ECONÔMICO E SOCIAL - IPARDES. Anuário estatístico. 2017. Disponível em: <http://www.ipardes.pr.gov.br/anuario_2017/1 territorio/tab1_1_1.htm>. Acesso em: 14/10/2019.

LEAL, L.; BIOND, D.; BATISTA, A. C. Influência das florestas urbanas na variação termo-higrométrica da área intraurbana de Curitiba - PR. Ciência Florestal, Santa Maria, v. 24, n. 4, p. 807-820, 2014.

MAACK, R. Geografia física do estado do Paraná. Ponta Grossa: Editora UEPG, 4. Ed., 2017.

MARTINS, L. F. V.; ANDRADE, H. H. B. de; HANISCH, R. F.; DE ANGELIS, B. L. D.; CAXAMBU, M. G. Análise da compatibilidade da arborização viária com o ambiente construído na cidade de Luiziana, Paraná, Brasil. Revista da Sociedade Brasileira de Arborização Urbana, Piracicaba, v. 6, n. 3, p. 103 - 127, 2011.

FLORESTA, Curitiba, PR, v. 50, n. 4, p. 1892 - 1901, out/dez 2020.

Carvalho Maria, T. R. B. et.al.

ISSN eletrônico 1982-4688

DOI: $10.5380 /$ rf.v50 i4. 66995 
MARTINI, A.; BIONDI, D.; BATISTA, A. C.; ZAMPRONI, K. A periodicidade diária do índice de conforto térmico na arborização de ruas de Curitiba-PR. Scientia Plena, v.9, n.5, p.1-9, 2013.

MACFARLANE, D. W.; KANE, B. Neighbour effects on tree architecture: functional trade-offs balancing crown competitiveness with wind resistance. Functional Ecology, Oxford, v. 31, p. 1624-1636, 2017.

MONTEIRO, M. M. G.; TETTO, A. F.; BIONDI, D.; SILVA, R. R. S. Percepção dos usuários em relação à arborização da avenida Cândido de Abreu - Curitiba - PR. Revista da Sociedade Brasileira de Arborização Urbana. Piracicaba, v. 8, n.2, p. 20-34, 2013.

MULLANEY, J.; LUCKE, T.; TRUEMAN, S. J. A review of benefits and challenges in growing street trees in paved urban environments. Landscape and Urban Planning, Amsterdam, v. 134, n. 2015, p. 157-166, 2014.

NASCIMENTO, R. C.; ALCÂNTARA, M. P.; ALENCAR, R. P.; PIMENTEL, D. J. O.; PINTO, A. V. F. Análise de riscos de acidentes na execução da poda na arborização urbana de Maceió-AL. South American Journal of Basic Education, Technical, Technological, Rio Branco, v. 4, n. 1, p. 233 - 240, 2017.

PRETZSCH, H.; BIBER, P.; UHL, E.; DAHLHAUSEN, J.; ROTZER, T.; CALDENTEY, J.; KOIKE, T.; CON, T.; CHAVANNE, A.; SEIFERT, T.; TOIT, B.; FARNDEN, C.; PAULEIT, S. Crown size and growing space requirement of common tree species in urban centres, parks, and forests. Urban Forestry \& Urban greening, Amsterdam, v. 14, p. 466-479, 2015.

ROMAN, M.; BRESSAN, D. A.; DURLO, M. A. Variáveis morfométricas e relações interdimensionais para Cordia trichotoma (Vell.) Arráb. ex Steud. Ciência Florestal. Santa Maria, v. 19, n. 4, p. 473-480, out.-dez., 2009.

SANQUETTA, C. R.; DALlA CORTE, A. P.; ROGLIN, A.; PIMENTEL, A. Relações diâmetro-altura para espécies lenhosas em um fragmento de floresta Ombrófila Mista no Sul do Paraná. Ieringia série botânica. Porto Alegre, v. 68, n.1, p.103-114, 2013.

SANTOS, N. R. Z. Dos; TEIXEIRA, I. F. Arborização de vias públicas: ambiente x vegetação. Porto Alegre: Palotti, 2001.

STRUNK, J. L.; MILLS, J.R.; RIES, P.; TEMESGEN, H.; JEROUE, L. An urban forest-inventory-and-analysis investigation in Oregon and Washington. Urban Forest \& Urban Greening, Amsterdam, v.18, n.1, p. 100-109, 2016.

TROXEL, B.; PIANA, M.; ASHTON, M. S.; MURPHY-DUNING, C. Relationships between bole and crown size for young urban trees in the northeastern USA. Urban Forestry \& Urban Greening. Amsterdam, v. 12, p. 144153, 2013.

VAILSHERY, L.S.; JAGANMOHAN, M.; NAGENDRA, H. Effect of street trees on microclimate and air pollution in a tropical city. Urban Forestry \& Urban Greening, Amsterdam, v. 12, p. 408-415, 2013.

FLORESTA, Curitiba, PR, v. 50, n. 4, p. 1892 - 1901, out/dez 2020.

Carvalho Maria, T. R. B. et.al.

ISSN eletrônico 1982-4688 